\title{
nature
}

\section{Assessment of Japan's universities long overdue}

The relationship between Japan's universities and the education ministry is too undemanding to allow critical appraisal of research. Rigorous external evaluation must become the norm.

A ssessment and appraisal are still alien concepts in Japan, particularly in the world of academia, where respect for the professor is paramount. Thus, it is not surprising that resistance from university faculty members to the introduction of external research assessment is widespread (see page 378).

But the writing is on the wall. Japan's student population is plummeting, owing to a long-standing decline in the birth rate, and universities are having to compete to survive. An increasingly visible part of that competition is on the research front where ever more sophisticated bibliographic analysis by third parties will reveal the performance of university departments whether they like it or not. Furthermore, while the Japanese government continues to be comparatively generous in funding science in a time of economic recession, there are growing calls in government circles for science to be targeted towards socio-economic needs.

That is a dangerous trend and Japanese academics should not bury their heads in the sand and hope that it will go away. Rather, they should face the inevitable and take the initiative in establishing a nationwide system of research assessment that takes account of the need for academic freedom. There are plenty of models around to learn from and, close to home, Singapore and Hong Kong are in this respect much more advanced (see Nature 389, 113-117; 1997).

External reviews of university departments and institutes have been carried out on an ad hoc and sporadic basis since early 1993 when Akito Arima, current minister of education, sent shock waves through Tokyo University by bringing in a team of overseas

\section{Hot seat in the kitchen}

\section{Last week's announcement that Britain will set up a Food Standards Agency opens a door for someone special.}

$\Lambda$ pplications will be invited later this year for the post of chief executive of a new agency, responsible for food safety researching, enforcing, advising government and informing the increasingly worried British public.

If your application is successful, you will have the satisfaction of (not before time) bringing the United Kingdom into step with other countries in detaching the regulation of food safety from conflicting agricultural interests and answering to a health ministry. You will control funds transferred from other ministries, plus up to $\mathfrak{£ 5 0}$ million (US\$82 million) levied from the food industry. You will have a powerful hold on the food safety agenda, in contrast, for example, to the fragmented situation in the United States. Because many of the issues are international in scope, you will have the opportunity to set an example to the world in assessing risks to health and, in collaboration with other ministries, the environment. The scientific research you control will be exemplary if (hopefully) unexciting in its attendance to public concerns about, for example, allergenicity from genetic modification. Your power to raid agricultural or other premises where standards are suspected to be researchers to assess its physics department. But such reviews are few and far between. They follow no consistent pattern. There is no system of benchmarking the assessments for comparison with other institutions, and the results are seldom made public. Furthermore, in only very rare cases have significant changes been made as a result of the reviews. Their prime motivation often seems to be to gain support for some new pet project, rather than being a genuine attempt to assess both the strengths and weaknesses of institutions.

The time is ripe for change. Arima, Japan's leading advocate of external review, has been appointed as head of both the education ministry, which oversees universities, and the Science and Technology Agency — both to be merged by 2001. Agency officials seem to have a greater awareness of the need for external assessment than their counterparts in the education ministry who, until now, have been only too willing to accept the sop of 'self-evaluation' proffered by powerful university professors and adopted by most universities in Japan as the norm.

In the long run, government officials will need to concentrate on value for money, and Japan will find its science increasingly evaluated in the international arena by complete strangers. This gaiatsu ('external pressure') will, along with the power of a handful of reformers in Japan, bring about the change that is inevitable. The academic community needs to work constructively with this change rather than seek to ignore it. This is essential if Japan is also to tackle the even more complex issue of giving much needed autonomy to universities to run their own affairs. lax should give rise to occasional dramas.

You can set new international standards in the access you provide to the public to basic and not so basic facts about food and some of the controversial technologies used in its production - communicating, for example, some sense of perspective of the comparative risks of contracting Salmonella poisoning from uncooked poultry (relatively significant) and digesting genes from genetically modified crops (negligible based on all the evidence so far).

You will need a cool head as you find yourself countering industrial lobbyists in insisting on more research before the introduction of novel foods and as you enrage some green groups with your judgement that some highly unnatural crops have indeed been adequately tested. Your minister can invoke national security and shut you up a power that may at times need to be resisted. And as the person ultimately responsible for several scientific advisory committees, you should be prepared for sleepless nights as equivocal evidence emerges that, if made publicly available, might bring some part or other of the food industry to its knees.

Still interested? 